\title{
Crises of Bosnia
}

\author{
Aleksandar Savanović \\ Faculty of Political Sciences \\ University of Banja Luka \\ savanovic_aleksandar@yahoo.com
}

\section{Doi:10.5901/mjss.2013.v4n9p539}

\begin{abstract}
Ever since its formation, Bosnia and Herzegovina has been considered a country of crisis and crises. However, the crisis is manifested in different ways on different levels, having also a different substance which cannot be reduced to the same. This must be emphasised, since Bosnia's nature of crisis is often used as an argument for certain unjustified political demands which in themselves do not reflect the actual context of the crisis. In this paper we argue that the crisis in $\mathrm{BH}$ can be broken down into three basic crises which constitute it: crisis of $\mathrm{BH}$ as a state, crisis of the Federation of $\mathrm{BH}$ and crisis of the Republic of Srpska. The crisis of the state is primarily a crisis of legitimacy: the Dayton Constitution is not genuinely accepted and it is constantly denied and disputed by the political representatives of all three constituent peoples, which results in a permanent political crisis. The crisis of the Federation of BH is a crisis of an unnatural constitution under the scheme "three peoples and two entities", which constantly produces situations of "tyranny of the majority". The crisis of the Republic of Srpska is mostly manifested as a crisis of economic inefficiency - the political situation in RS is relatively stable and it provides a sound basis for addressing the key, economic problems. However, the Government has been showing the inability to cope with such demands. These crises are, naturally, intertwined, but they are still fundamentally different: $\mathrm{BH}$ as a state and the Federation of $\mathrm{BH}$ are also affected by problems of economic efficiency, while the RS faces challenges to its legitimacy. Nevertheless, the dominant aspects of crises in these three segments of the Bosnian society can be clearly marked and delineated. It is possible to use this diagnosis of crisis to develop an appropriate anti-crisis policy.
\end{abstract}

Keywords: Crisis, Bosnia and Herzegovina, Federation of BH, Republic of Srpska.

\section{Introduction}

Ever since its formation as a state, Bosnia has been a country of crisis and crises. Ever since the independence referendum, through which the state was quasi-constituted, until the current frictions, Bosnia has been an „unfortunate" ${ }^{1}$ state in the state of permanent crisis, on all levels and in various forms. Transition after the civil war has not been happening in the form of gradual opening of the $\mathrm{BH}$ society and establishment of the state, but $\mathrm{BH}$ has remained „imprisoned" in a sort of closed society in the state of permanent conflict, which fails to start functioning. Such a society blocks itself, producing permanent decline in standards in terms of economy, permanent blockade of political processes, and complete devastation in terms of culture. However, this crisis is manifested in different ways on different levels, having also a different substance which cannot be reduced to the same. This must be emphasised, since Bosnia's nature of crisis is often used as an argument for certain unjustified political demands which in themselves do not reflect the actual context of the crisis. Thus, for example, Bosniak political representatives instrumentalise the thesis of BH crisis for the purposes of unitarisation, while political representatives of the Republic of Srpska (RS) observe it as a justification of the request for secession. Neither of these represents the actual situation. Quite contrary, this is one of the factors of crisis maintaining and deepening.

Generally, the crisis in $\mathrm{BH}$ can be broken down into three crises which constitute it: crisis of Bosnia and Herzegovina $(\mathrm{BH})$, crisis of the Federation of $\mathrm{BH}(\mathrm{FBH})$, and crisis of the Republic of Srpska (RS). These crises are, naturally, intertwined, and each of them is more or less present on all three levels that we observe here, but on each of

${ }^{1}$ Even though the term "unfortunate" is not something that can be treated as an objective attribute in terms of scientific rigours, it is frequently present as a description of Bosnia in Bosnian literature. For example, Bosnian writer Dervis Susic, in his work "Phantoms", uses this term exactly to describe Bosnia. In the context of newer research, the term has obtained objective connotations as well. In December 2012, the report Business Insider was published, indexing the "poorest countries" in the world. According to this report, BH was seventeenth on the list of 20 "poorest" countries. Key criteria were unemployment rate and inflation, which in $\mathrm{BH}$, according to the data taken over from CIA Factbook, were as follows - unemployment $43.3 \%$ and inflation 3.8\%. 
them one aspect of the crisis is present as defining and dominant.

\section{Crisis of the State}

The crisis of the state is primarily a crisis of legitimacy. Through the independence referendum², unfortunately, $\mathrm{BH}$ was not "immaculately conceived", but it came to being in the sin of overruling and supremacy of one over other two, and this sinfulness has been following Bosnia until today, making it impossible for the system to start functioning. $\mathrm{BH}$ is an "unwanted child" that, in this form, is not wanted nor accepted by any of its creators. Serbs and Croats exhibit overt or covert separatist ambitions ${ }^{3}$, while Bosniaks do not give up on the project for a unitary state with Bosniak/Muslim majority, under the guise of a "civil" state.

Such lack of acceptance is manifested in political practices of ignoring the constitutional and legal frameworks of the state by its highest authorities, who, taking into account the fact that the Constitution has not been accepted on the basic level, do not feel they are bound by it.

Challenge to the Constitution is generally based on three key arguments [Steiner C., Ademović N.; 2010: 29-34]. The first is that the Constitution of $\mathrm{BH}$ was not adopted in a normal procedure of constituting in the social contract act, but it was octroyed, above all under the pressure and will of the international community. This means that $\mathrm{BH}$ does not have its "internal recognition" [Kecmanović N., 2007:5], and this fact creates wide opportunities for challenges. Thus, for example, at one of the recent sessions of the non-governmental organisations Circle $99^{4}$ this argument was presented by Anton Bebler. Later he expanded it towards the request for the Dayton Agreement creators, since they have taken some kind of implicit responsibility for the functioning of $\mathrm{BH}$, to have the obligation to force the adoption of a new Constitution by $\mathrm{BH}$ citizens and institutions. Political representatives of Bosniaks use this argument to challenge the Dayton Constitution and to give the legitimacy to the Constitution of the Socialist Republic BH, while political representatives of Serbs use it in the sense that BH state, as such, emerged through illegitimate violation of the will of the Serbian people that in the plebiscite voted against $\mathrm{BH}$.

Another significant argument is present in certain extreme political circles, and it is related to the challenge to the legitimacy of certain constitutional solutions. [Silajdžić H., 2000:116] For example, it is stated that "the Constitution contains norms which are contrary to the international law." [Steiner C.; 2010:31] In this way, the legitimacy of the existence of the Republic of Srpska is challenged, and this entity is branded as a "creation of genocide" which came to being through "mass Serbian aggression" and "ethnic cleansing", even though, of course, it is a Constitutional category.

The third argument is that the Constitution has proven to be inefficient in practice, and that $\mathrm{BH}$ cannot function within the scope of such arrangement. The key disadvantage is in the overly strong mechanisms of protection of collective rights, which allows for the blockade of decision making on different levels. [Schmunk M.; 2009:18-20]

The hypothesis of the Constitution illegitimacy is generally further extended to the statement that the function of the Dayton Agreement was to finish the war [Holbrook R.; 1998:336; Izetbegović A.; 2001:342], and not to provide a specific political and legal framework based on which the state would continue to exist in peace.[Silajdžić H.; 2000:113]

Contrary to the "Dayton" BH, the "Brussels" BH is promoted, and generally in the form of unitarisation. Specifically, the Annex 4 is a markedly consociational Constitution [Savanović A.; 2011:20]. Under the guise of European integrations and through the strategy of transformation towards the "Brussels" BH, this Constitution tends to be transformed into a majoritarian and unitary one. On the background of this strategy is the concept "Dayton 2" which is from time to time promoted by certain influential political actors. Recently, U.S. Congressman and member of the House Committee on Foreign Affairs Russell Carnahan has advocated such an approach, defining Dayton as a "temporary solution" which has "become an obstacle to future progress". [Carnahan R.; 2012] Also, the newly appointed U.S. Secretary of State John Kerry, in one of his columns from 2009, wrote that BH was a "political prisoner of past agreements", repeating the paradigm that Dayton ended the war but did not create an efficient state. He even advocates a "great diplomatic

\footnotetext{
2 It was held on 29th February and 1st March 1992. At the referendum, $64.31 \%$ of all citizens voted (out of which a huge majority, $99.40 \%$, voted for independence), most of them Muslims and Croats, while vast majority of Serbs boycotted the voting. Earlier, on 9th and 10th November 1991, Serbs organised the Plebiscite, when they voted to stay in Yugoslavia.

${ }^{3} \mathrm{~A}$ poll in 1997 showed that $91 \%$ of the Bosnian Serbs and 84\% of the Bosnian Croats were against a unified Bosnian state, as opposed to $98 \%$ of the Bosnian Muslim population who were for it. [Woodward, S.; 1999:96] Compare: Skoko, B.; 2011.

${ }^{4}$ The session under the working title Through the cooperation of state and foreign intellectual and political actors towards the new Constitution of $\mathrm{BH}$, held on 19th January 2013. As the media reported, professor Anton Bebler said: "The existing Constitution was adopted by foreigners, it was written by foreigners, and also, it was forced, which means that it should be null and void from that point of view." (cited from: Dnevni Avaz, 20th January 2013).
} 
investment" which would direct the political processes in $\mathrm{BH}$ in this direction.

The thesis we wish to present in this paper is contrary to the previous position. Indeed, even though the Annex 4 Dayton Agreement is not a Constitution which emerged in a classical constitutional procedure ${ }^{5}$, it still served for $\mathrm{BH}$ to gain some kind of a framework, and relying on it, it had its opportunity to start function. However, this has not happened, and ever since the beginning, up until now, we witness the instruments of the state, which could function themselves, being usurped and misused by certain actors. Last year's scandal involving the voting of BH representatives in the UN General Assembly on the Resolution on Syria [GA/11266/; 2012] proposed by Saudi Arabia is just one example. As it is well-known, the Constitution of $\mathrm{BH}$ provides that the foreign policy of $\mathrm{BH}$ is under the jurisdiction of the Presidency of $\mathrm{BH}$, and if there is no agreement between all three members in the Presidency, the BH representative in the UN should abstain from voting. (Constitution of Bosnia and Herzegovina, V/2, c-d). This procedure is obviously very simple and clear. However, by means of will of one political actor, in this case the Minister of Foreign Affairs Zlatko Lagumdzija, and his abuse 6 of the institution he headed, this simple and clear procedure became a source of internal political crisis in $\mathrm{BH}$, which lasted for several months. This example is very illustrative, since it calls into question the claim that Dayton was obsolete because it prevents BH from functioning "normally". Contrary to this position, the previous example may serve to show that the constitutional framework is more than enough for efficient governance, the problem actually being in unconstitutional practices that usurp it. Actually, there is not such a constitutional framework which would be able to withstand behaviour of those who ignore it: for a Constitution to "function", it is necessary for it to be accepted by all actors who would, when acting, always stay within the constitutional framework.

From this premise we deduce that the crisis of $\mathrm{BH}$ is unsolvable on the level of development and improvement of the existing constitutional solutions (even though these are, of course, necessary, inevitable and natural), but only and exclusively through the previous consensus on the actual, and not just declarative acceptance of the Annex 4Constitution. If this diagnosis is correct, we can even say that those who propose a form of revision and "Dayton 2" actually only deepen the crisis of $\mathrm{BH}$ in favour of separatist interests of the lobbies they work for. The problem is not in the fact that the Constitution is not good, but in the fact that it is not observed.

Going beyond this, we may suspect that permanent blockades and institutional incidents are produced purposefully, to demonstrate the necessity of international diplomatic intervention in the constitutional order of Bosnia and Herzegovina. Thus, for example, the long-term crisis related to relatively simple solution of the problem referring to the decision of the European Court of Human Rights in the Sejdic-Finci case is observed as an artificial product of crisis in order to use this request for a limited correction of the Institution to enter its full reconfiguration. All the actors are hoping to get more than they already have through this reconfiguration, while using the Decision to realise certain goals which are not included in it. [Decision of the European Court of Human Rights in the Sejdic-Finci case; 2010] Therefore, "Bosniak" political representatives believe that the Decision cannot be realised only within the domain of its merits, since this also requires a complete revision of the Constitution. ${ }^{7}$ This revision is again observed as the reinstalling of the "civil" model of $\mathrm{BH}$, which is to be presented as the only model guaranteeing equal rights to all citizens. ${ }^{8}$ On the other hand, the concept of consociation, with the constituent peoples as holders of the consociational mechanism, is always in one way or another excluding "Others", if not de jure, then de facto for sure. [Bose S.; 2002:250-252] Certain theorists label the opinion about the necessarily consociational three-nation nature of $\mathrm{BH}$ as a retrograde nationalist, and even "neo-Nazi" (!) approach. [Zgodić E.; 1996:12] It is obvious that the extreme escalation of the civil versus national concept here serves as an argument for challenging the Dayton Constitution. [Ćurak N.; 2004:105]

\footnotetext{
${ }^{5}$ Even though this cannot be argued over, taking into account the fact that Parliaments voted on the Dayton Peace Agreement, and the Constitution is an integral part of this document - Annex IV.

${ }^{6}$ Even though the facts of this case are not entirely clear and the controversy remains unexplained.

${ }^{7}$ This is commonplace of certain circles of the political scene of Sarajevo. Thus, for example, Academician Muhamed Filipović, in his article Political and legal pattern for the destruction of the fictional monopoly [2012], put forward the hypothesis that the discriminatory provision treated by the Decision actually represents a necessary consequence of an „absurd principle“ that „in states in which several peoples live there are chosen, that is, "constituent peoples", and that this necessarily implies that „all others are of lower status and rights". He further extends the argument towards the historical character of the nation, which is in no way a necessary framework of identity, but an arbitrary measure. As such, taking into account that it is a source of discrimination, "it must be entirely abolished... or suppressed into the sphere of pure formality". Since "the existing system cannot be crushed from the inside" this must be done "from the outside". In this sense, Academician hopes that the current initiatives from the EU and the USA represent the "beginning of a new era" for $\mathrm{BH}$.

${ }^{8} \mathrm{An}$ additional argument used to support the "civil" model of $\mathrm{BH}$ is that even the Socialist BH, from ZAVNOBiH, was conceived as a "civil" republic, with "Bosnian people" as the bearer of sovereignty. [lbrahimagić 0.;2001:47.] This argument is in direct contrast with the „tripod" concept which determines the three-nation basis of $\mathrm{BH}$ in the text of ZAVNOBiH.
} 
However, contrary to these positions, we believe that the consociational model of democracy, which is imminent for the "Dayton" BH, represents a natural model for pluralistic societies and most countries with multi-national composition actually apply it. [Lijphart A.; 1999: 31-39] In any case, there is no guarantee that the "majority" model would be more efficient. ${ }^{9}$ Quite contrary, most experts for democracy in divided societies believe that the key prerequisites for its functioning are these two consociational elements: autonomy of groups and division of powers between groups. [Lijphart A.; 2004: 97] On the other hand, specific historical experience of successful multi-national countries, such as Switzerland, speaks in favour of the consociation in pluralistic communities. Therefore, we believe that the crisis in the functioning of $\mathrm{BH}$ as a state is above all a result of the challenges to the existing Constitution by the key actors, and not of its objective deficiencies, even though these certainly do exist.

\section{Crisis of the Federation of $\mathrm{BH}$}

The crisis on the level of the FBH is manifested as a crisis of unnatural constitution under the scheme "three peoples in two entities". It is completely obvious that the natural scheme for a country with the entity organisation would be three peoples in three entities, that is, a federal/confederal state consisting of three federal units. However, for the sake of tactical demands of the historical moment, the Croatian corpus in BH has accepted the Muslim-Croat Federation..$^{10}$ Now it faces the usurpation of its mechanisms of power by the Bosniak majority and its political representatives. [Bose S.; 2002:88]

Therefore, the key problem of the FBH is the majorisation of the Croat minority by the Bosniak majority. The Federation is a striking example of what is known in the democracy theory as the "tyranny of the majority" - an anomaly of democratic process especially dangerous in pluralistic communities. This means that the representatives of the Croatian people are often subject to overruling in the legislative bodies on many issues of national interest. ${ }^{11}$ The most notable example has been the election of the Croat member of the Presidency of Bosnia and Herzegovina, who was imposed on Croatians by Bosniak parties at two previous electoral cycles. Member of the Presidency of BH representing the Croatian people is Zeljko Komsic, who does not come from the Croatian Democratic Union (HDZ), the party which has by far the best electoral results among Croatians in $\mathrm{BH}$, but from the Social Democratic Party (SDP), party formally without national connotations, but whose $90 \%$ of members are Bosniaks/Muslims. ${ }^{12}$ Another current example is the attempt to establish a "Croatian" TV channel. Although the right of minority groups to have a public broadcaster is undoubtedly a democratic achievement of modern democratic states and a right guaranteed by relevant documents, including also the European Convention on Human Rights (Article 10), the Croatian people has not been able to realise this right in the parliamentary procedure.

The crisis with the problem of adequate representation of Croats in the FBH government has been particularly deepened after the previous general elections. At that time, two leading Bosniak parties, SDP and SDA, organised the Government with minor Croatian parties, HSP and NSRzB, thus excluding two leading Croatian parties. Actually, in this way, representation of the majority of Croats in the executive authorities was excluded. Practically from the end of the elections, the FBH has been in the state of permanent crisis: the Government of the Federation has been in the process of constitution ever since the elections, but it still cannot be constituted, and the chances of this happening in a (semi)legal way have been diminishing. ${ }^{13}$ This creates a stalemate situation in which the parliamentary majority does not

\footnotetext{
${ }^{9}$ An overly rigid application of the majority model during the period of the SFRY dissolution led to a very strained situation of the "tyranny of the majority", which forced the minority to resort to "abnormal political behaviour" [Dahl R.; 1991: 22]. We believe that a strong foundation of the claim is that this majority "civil" model of democracy itself was the cause of the civil war in $\mathrm{BH}$.

10 Formally, this was realised through the Washington Agreement from 1994, which served to end the armed conflict between the HVO (Croatian Defence Council) and military forces of the government in Sarajevo.

${ }^{11}$ It is very instructive to the case of $\mathrm{BH}$ as a whole that practices of overruling have been intensified since 2000 , when the Constitutional Court adopted the decision of the constitutionality of all three peoples on the territory of entire $\mathrm{BH}$. High Representative Wolfgang Petritsch forced the amendments to the Constitution of the FBH [Amendment III and Amendment XXVIII] and the RS [Amendment XLIV and Amendment XLVII], in order to comply with this decision. However, in practice, the effect has been quite opposite.

12 For example, at the elections held in 2010, in Kalesija, municipality with a Bosniak majority, Željko Komšić got 7033 votes, while Borjana Krišto from HDZ got only 27 votes [Central Election Commission BH; http://www.izbori.ba/]. In this way, due to the majority voting model without an ethnic clause, Bosniaks are able to elect the Croat member of the Presidency, and they de facto elect two members of the Presidency, while Croats elect none.

${ }^{13}$ Running each other down in permanent political skirmishing, authorities in the FBH simply cannot focus on the economic development and actual living problems. It is not a wonder that strikes and protests are the permanent image of the Federation. Trade unions threaten with protests of 50,000 workers, at the same time hoping for a wider civil rebellion. This is the result of the lack of compliance with the
} 
have the majority in the executive authorities too. Painful and exhausting negotiations of the new "four"14 have proven to be ineffective. The consequence of this blockade is the vast majority of the Croatian people de jure having their representatives, but de facto it is not represented in the executive authorities of the FBH.

Bearing in mind such practices, there is no doubt that Croats' requests for a form of constitutional protection of their rights are completely natural and justified, in order to prevent similar practices. Most often it is manifested as the request for the "third entity", which would practically transform BH into a confederal community of three constituent peoples with three ethnically defined territorial units. [Bose S.; 2002:28] Obviously, the concept of the third entity and confederalisation of $\mathrm{BH}$, in spite of seeming to be natural for a type of state such as $\mathrm{BH}$ and being widely present in the modern political practice, it is not the only model through which the request for equality of a smaller group could be realised. Modern constitutional practice has different mechanisms of the minority protection, and Dayton itself is one of the models which could be used to achieve this. Therefore, for example, the equality of Croats could be ensured through the introduction of additional consociation mechanisms into the Constitution of the Federation of $\mathrm{BH}$ and strengthening of the existing ones. Consociation is not a model which is exclusive for territorially concentrated national communities within the scope of one country. For example, the concept of "non-territorial autonomy" is an alternative model that could function in the Federation. Although it is still early to give the final assessment, it seems that in this frame is the initiative launched by the U.S. Embassy in BH in January 2013.15

What has to be considered is that the key problem of the Federation is the "Croatian issue", and not the cantonal organisation. This has to be emphasised since certain recent initiatives seek to interpret the cause of the crisis of the FBH as a primarily efficiency problem which emerged as a consequence of the complicated cantonal organisation. ${ }^{16}$ The structure of the $\mathrm{FBH}$, organised through the system of 10 cantons and central entity Government, is not only complicated and difficult to manage, but also economically too expensive, and there is no doubt that there is the need to reorganise it. However, this reform must also deal with the main problem of the FB, that is, the "Croatian issue", and it must not remain on the level of the modernisation of government only.

\section{Crisis of the Republic of Srpska}

Crisis of the Republic of Srpska is primarily the crisis of economic inefficiency. Even though the legitimacy of the RS is challenged, this challenge does not come from the inside, as the vast majority of the RS citizens have no doubt about the political framework they live in. Political struggle between two dominant parties, Alliance of Independent Social Democrats (SNSD) and Serbian Democratic Party (SDS), regardless of its severity, is channelled within the normal

agreements reached in May 2012, when approximately 8,000 workers took part in the warning protest in front of the federal Government. The Government, of course, was not able to deal with the conclusions from the agreement simply because from the crisis of the formation of parliamentary majority it jumped directly into the identity "crisis" of what "constitutes" the parliamentary majority, and in such an atmosphere and situation it is clear that workers' requests cannot be on the agenda for real. As it was stated by the trade union itself, none of 40 agreed conclusions was realised, and the question arises whether these conclusions are valid, taking into account that the previous parliamentary majority, that is, "platform parties", were the ones that committed to them.

${ }^{14}$ After the elections, the parliamentary majority (SDP, SDA, HSP, NSRzB) was established without taking into account the electoral legitimacy of the Croat people, but it was compatible with the executive powers, and the Government reflected the parliamentary majority. Nowadays, the situation is opposite - leading Croat parties are involved in the government (SDP, SBB, HDZ and HDZ 1990), but now the parliamentary majority is no longer compatible with the Government. This is a consequence of the fact that the Government cannot be legally changed without the approval of Zeljko Budimir. Having in mind that he comes from the HSP which would lose its place in the Government in that way it is obvious that it is not realistic to expect this. Thus, consequences of political adventurism with an attempt of illegitimate exclusion of the HDZ and HDZ 1990 ended in a blockade which will probably last until the new elections in 2014.

${ }^{15}$ Ambassador Patrick Mook formed a team of experts in order to solve the problem of democratic deficit in the Federation of $\mathrm{BH}$. The initial diagnosis, presented by one of the members of the expert team, professor of constitutional Law Kasim Trnka, states that the key problem of the FBH (and the state as a whole) is a relationship between the civil and national, which we tend to agree with. Also, the assessment that this does not necessarily imply further confederalisation and a "third entity" is entirely correct. However, his assessment that the consociational model of democracy is also not good, and that such a solution is "harmful to Bosnia", raises suspicion that even before the beginning he limited the theoretical framework for movements, up to the measure where he is left with only one of the options of the "majority" model of democracy. However, it is clear in advance that any form of this model can hardly get support from a majority of Croats. Moreover, it is also theoretically questionable for such a difficult case as the FBH.

${ }^{16}$ The strategy of the FBH organisation with the model of six cantons plus Sarajevo as a district was proposed at a public discussion in late January by the Law Institute in BH. The solution for the "Croatian issue" is seen in the "unification of cantons with Croat majority, such as the Livno Canton and West-Herzegovina Canton", as presented by one of proponents, Muhamed Mujkic. 
parliamentary democratic procedure in which all actors act inside the boundaries of what is defined in the Constitution. The legitimacy of the RS is, however, challenged from the outside - by Bosniak political representatives, who are trying to define the RS as a "creation of genocide". Still, this challenge is of completely different sense and capacity from that which we discussed for the level of $\mathrm{BH}$ or the $\mathrm{FBH}$, whose legitimacies are challenged from the "inside", by their citizens and constituent peoples.

Thus, contrary to those other two levels, political situation in the RS is relatively stable and it provides a sound basis for dealing with key, economic problems. However, this segment was exactly where the Government has failed, and with a series of wrong measures and complete lack of vision it has led the RS towards dramatic economic crisis. Although the economic situation in the RS is undoubtedly highly influenced by wider "objective" factors such as the global economic crisis and previously described blockade of the country, as well as permanent attempts to abuse the institutions of $\mathrm{BH}$, there is still no doubt that the results of the current Government's management are devastating. A popular thesis of the "better entity" or of "the only self-sustainable part of BH", promoted by the political representatives of Serbs, could possibly be true only if observed in the context of catastrophic situation in BH as a state and in its "bigger"17 entity, but it is debatable even in this case. However, if observed in terms of the real situation, the RS is in a deep economic and social crisis, probably the worst one since the war ended.

The key parametres suggest the following. [Savanović A.; 2012] Unemployment is very high, and from the economic point of view it is unacceptable in the long term. The number of unemployed persons at the Employment Office is 151,596, and this amounts to almost $45 \%$. Industrial production in the period January-June 2012 was $4.2 \%$ lower than in the same period of the previous year. ${ }^{18}$ It is evident that the external trade deficit in such circumstances must be enormous. On the level of the RS, in the period January-June 2012, coverage of import with export was catastrophic at $55 \%$. A logical consequence is the fact that the debt is reaching alarming proportions. The debt has exceeded $50 \%$ of the GDP. It is already clear that the RS is no longer able to take development loans, and now it can only reschedule the incoming commitments that cannot be serviced. But even this budget balancing has been increasingly questionable, and the budget framework has become problematic. In the Economic Policy for 2013, the Government was forced to concede defeat by introducing wage cuts. This dramatically affects the already low living standard of the population. Practically all strategic sectors are devastated- Railway, Forests of Srpska, Post of Srpska, Pension and Disability Insurance Fund, health care system, etc., since for years these have only served to accumulate losses. The ruling party itself eventually had to acknowledge these facts and to deny the confidence in the Government which resigned in late February.

These facts show that permanent emphasising of the so-called "political issues", issues from the field of constituency, promoted by the current authorities in the RS, is actually only an artificially imposed dilemma. The inability of the current government to efficiently deal with the problems of economic efficiency forced it to go back to the retrograde nationalist rhetoric and production of enemies. The strategy of the current government is to use constant emphasising of political crisis and fictional enemies ${ }^{19}$, to cover up the poor and inhospitable management. The lack of consensus concerning the Dayton Constitution serves as a mechanism to hide the incapability of the government to solve economic problems. We argue that the doctrine "defence of Dayton", promoted by the RS Government in the past seven years, is not the actual position of sincere devotion to the Constitution of $\mathrm{BH}$. This is clearly evident from the rhetoric which constantly promotes the thesis of "temporariness" of Bosnia and Herzegovina, of Bosnia as an "artificial" creation, etc., advocated by the ruling party. Even though these diagnoses represent largely accurate descriptions of the situation on the ground, in this case they are only instrumentalised with the aim of distracting the public from the fact that the living standard has fallen enormously and that citizens have been poorer and poorer. ${ }^{20}$

\footnotetext{
${ }^{17} \mathrm{BH}$ is composed of the FBH covering approximately $51 \%$ and the RS covering approximately $49 \%$ of its territory. This is why certain political actors mention the FBH as the "larger entity".

${ }^{18}$ In the construction sector, value of performed works in the period January-June 2012 was 15\% lower than in the same period of the previous year. Only in the footwear manufacture sector, number of workers decreased from 40,000 to 10,000, and the Association of textile, leather and footwear has warned that this branch might "crash" completely, with "10,000 workers ending up in the streets". According to representatives of this Association, this is happening because customs duties on imported raw materials are paid up to five times more by our entrepreneurs than by those from the EU. For example, customs duties on rubber soles here are 15\%, while in the EU they amount to $2.5 \%$, and for shoe buckles - $15 \%$ here and $2.7 \%$ in the EU.

${ }^{19}$ For example, recently, the threat of "spring"-revolution in the RS announced by the President of the RS.

${ }^{20}$ Obviously, here we have an example of a "self-fulfilling" prophecy: the thesis of "unsustainability" of BH and unwillingness to be genuinely committed to the state really makes this country "impossible". This mechanism used by the current authorities in the RS is enhanced by a compatible attitude of Bosniaks, who claim that such BH is "dysfunctional", and Croats, who argue that BH is "unjust". Thus, we reach the initial premise that all three constituent people actually do not want a state like this one.
} 


\section{Conclusion}

If the previous analysis of the type and nature of the crisis, divided into separate parts of $\mathrm{BH}$, can be understood as correct, then the anti-crisis priorities are evident as well.

Firstly, on the level of $\mathrm{BH}$ as a state, it is necessary to work towards the acceptance of the existing constitutional order by all actors, especially by avoiding the affirmation of a potentially dangerous illusion referring to a possible amendment to the Constitution through some kind of external intervention. A fundamental step in this direction would be the subsequent adoption of the Constitution in a parliamentary procedure, which has occurred as an initiative at one point, but did not gain the necessary support. An act like this one would certainly relax the relations in the country and crush the illusions of all actors that they could gain more than the Constitution offers through possible favourable developments on the wider international stage. The international community's support, if needed by Bosnian political actors, should be directed towards the establishment of what $\mathrm{BH}$ currently is but for now only on paper, and not towards the revision of the Dayton $\mathrm{BH}$. On the level of the $\mathrm{FBH}$, the Constitution of the FBH should be amended, in order to enable the solution of the Croatian national issue. This can be done through the transformation of the FBH from the cantonal to some other form of entity organisation or through the change of the electoral law and legal procedures in the Parliament in the manner which would ensure de facto equality for Croats. When it comes to the RS, the focus must be placed on the economic aspects, avoiding counter-productive and unnecessary political crises on the state level.

Secondly, which becomes evident from our elaboration, is the fact that certain popular myths referring to the solution of the crises of $\mathrm{BH}$ are nothing else but that - myths. One of these is that the integration of the country into the EU automatically solves the "problem of Bosnia". This is obviously untrue, taking into account the fact that the EU accession process does not directly affect the structure of $\mathrm{BH}$ as a state in any of the key aspects of the crisis. Thus, the problem of rejection of the Constitution is completely independent of the reform of the Constitution required by the EU integration process. The same is true for the Federation, which even with its existing organisation can withstand the process of integration reforms, and this is after all confirmed by the fact that some of European countries are organised by the canton model. For the RS, the situation is especially clear: integration processes represent an opportunity but also a threat to domestic production, depending on the previous preparedness of certain space for integration in a highly complex market such as the EU. Therefore, even though the models presented here are simplified schemes, they still represent the complexity of the BH crisis which cannot be solved by simplified binary "or-or" approaches, as it requires a sophisticated and detailed strategy.

\section{References}

Bose Sumantra, Bosnia After Dayton [Hurst and Company, London 2002]

Ćurak Nerzuk, Dayton Nationalism [buybook, Sarajevo 2004]

Dahl Robert, Democracy and Its Critics [Yale University Press, 1991]

Filipović Muhamed, Political and legal pattern for the destruction of fictional monopoly [Dnevni Avaz, 2nd February.2013]

Holbrook Richard, To End a War [Šahinpašić, Sarajevo 1998]

Ibrahimagić Omer, Serbian Denial of Bosnia and Herzegovina [Magistrat, Sarajevo 2001]

Izetbegović Alija, Memories [Šahinpašić, Sarajevo 2001], pg.342.

Kecmanović Nenad, Impossible State [Glas Srpske, Banja Luka 2007]

Lijphart Arend, Patterns of Democracy: Government Forms and Performance in Thirty-Six Countries [New Haven, Yale University Press, 1999]

Lijphart Arend, Constitutional Design for Divided Societies [Journal of Democracy, Vol.15, No.2., April 2004; pg.96-110]

Metz Corrina, The Role of the International Community in the Police Reform in Bosnia-Herzegovina 2004-2008 [NDA, Vienna 2010]

Pejanović Mirko, Political development of Bosnia and Herzegovina in the post-Dayton period [Šahinpašić, Sarajevo 2005]

Decision of the European Court of Human Rights in the Sejdic-Finci case [ANURS, Banja Luka 2010]

Carnahan Russell, "Bosnia Needs Dayton 2" [Interview for: Dnevni Avaz, 4th August 2012]

Savanović Aleksandar, Consociational Nature of the Annex 4 [in: Serbian Legal Thought (Srpska pravna misao), year XXXVIII, No.45, Banjaluka 2011, pg.19-36]

Savanović Aleksandar, Plan for the analysis of the current situation in the Republic of Srpska [NoviReporter No.494; 2012; available at: http://www.nspm.rs/]

Schmunk Michael, A Country with Several Nations, but without a Proper State? Why Bosnia Doesn't Work? [Supporting Bosnia and Herzegovina: The Challenge of Reaching Self-Sustainability in Post-War Environment; NDA, Vienna 2009, pg.15-30]

Silajdžić Haris, On the Road to a Modern State [VKBI, Sarajevo 2000]

Skoko Božo, What do Croats, Bosniaks and Serbs think about each other, and about Bosnia and Herzegovina [Friedrich-Ebert-Stiftung, Sarajevo 2011] 
Steiner Christian, Ademović Nedim (ed), Constitution of Bosnia and Herzegovina - comment [Konrad Adenauer Stiftung, Sarajevo 2010] Woodward Susan, Bosnia and Herzegovina: How Not To End Civil War; 1999 [in: B.F.Walter, J.Snyder (ed); Civil Wars, Insecurity and Intervention, New York 1999]

Zgodić Esad, Civil Bosnia [Ritam, Tuzla 1996]

GA/11266/Rev.1., 03. August 2012. [http://www.un.org/ News/Press/docs/2012/ga 11266Rev1] 